\title{
Integrated Mobile Learning Education Supply Chain Management for Higher Learning Institutions
}

\author{
Mashiour Rahman, Rosshairy Abd. Rahman, Mamun Habib
}

\begin{abstract}
The mobile devices are used to execute the teachinglearning-evaluation process in Mobile Learning (m-learning) methodology. M-learning is a trending field in educational organizations, companies, and for individual study. With the explosion of mobile device ownership among the users aged within 18-29 years who are also the attendees of the higher learning institution (HLI), gives us the opportunity to consider the use of m-learning methodology to be embedded in the HLI beside traditional methodologies. Exceptional circumstances such as the COVID-19 pandemic when traditional face-to-face methodology suddenly changed to online paradigm, is also forcing us to strongly consider the m-learning approach. However, HLI may not have a general policy to implement m-learning into the traditional learning environment. A proper educational outcome needs to be configured to implement a new process into the traditional process. Therefore, a model integrating the m-learning aspects and the education supply chain management factors obtained from this study may benefit the stakeholders of HLI, especially educators and students.
\end{abstract}

Index Terms - Mobile learning, Supply chain management, HLI, education, m-learning

\section{INTRODUCTION}

$\mathrm{T}$ HE changing nature of the expectations of the global market always creates a change in the requirement of the skillset of the graduates. Specially, the adoption of technology in the society is continuously changing the nature of knowledge gathering and delivering paradigm. Higher learning institutions (HLI) are under pressure to match the market requirement of the skilled graduates. This can be done by improving the quality of teaching and learning by integrating up-to-date technologies [1]. The implementation of m-learning alongside traditional methodologies in the HLI is now in highest consideration as the possession and usage of mobile devices has increased among the attendees of the higher learning institution [2]. Such integration may contribute to the requirement of the society for a more adaptable and individualized education putting the learners at the center of the teaching-learning process [3], [4].

Mashiour Rahman, PhD Candidate,

Universiti Utara Malaysia (UUM),

mashiour@gmail.com.

Dr. Rosshairy Abd. Rahman, Senior Lecturer,

Universiti Utara Malaysia (UUM),

shairy@uum.edu.my.

Dr. Md. Mamun Habib, Professor, Independent University Bangladesh (IUB), mamunhabib@iub.edu.bd.
Employing an additional system into the existing system depends on the proper educational outcome for all stakeholders of the institution. The educational outcome depends on different factors within each aspect of education suppliers at different decision levels of an education institution. The stakeholders of an educational institution require the appropriate relationship among these components with a targeted educational outcome to decide on implementing m-learning into the traditional learning environment [5]. This study is to embed the aspects of educational institution and the m-learning environment to create an integrated model with measured relationship among all the aspects for the stakeholders understand, measure, and decide on the integration process.

\section{LITERATURE REVIEW}

Mobile learning (m-learning) methodology is a teachinglearning-evaluation process that is executed through mobile devices and is a trending field in educational organizations, companies, and also for individual study [6], [7]. Mobile learning facilitates both individual and collaborative learning allowing truly anywhere-anytime personalized learning. It removes some of the formality and adds variety to the conventional lessons/courses [8]. M-Learning encapsulates different features of learner-centered pedagogies. This includes discovery learning, constructivist learning, problem-based learning, situated learning, etc. which raises self-confidence and self-esteem of the learners [1], [9].

Integration of m-learning environment into HLI can deliver learners with several advantages such as ubiquitous access to media, rich learning content, social interaction and collaboration with peers, and just-in-time learning at anywhere and anytime through wireless network technologies [4]. Exceptional circumstances such as the COVID-19 pandemic when traditional face-to-face methodology suddenly changed to online paradigm, is also forcing us to strongly consider the $\mathrm{m}$ learning approach. However, the integration of m-learning has a lot of associated challenges. The diffusion of m-learning in higher educational institutions may result in significant cultural change. The pedagogic practices needs to be changed and new technologies and teaching methodologies must be adapted by the university educators, which might be unfamiliar to them [2]. Furthermore, some courses may not be suitable for the mlearning environment [10]. More importantly, Internet connection issues concerning bandwidth, security, speed, reliability and network coverage of service provider warrant much attention in ensuring the smooth implementation of $\mathrm{m}$ learning [11]. There is also the issue of university educators 
being uncomfortable using technology given that they may comprise of earlier generations.

The aspects of m-learning environment can be described in three aspects - technological aspects, learning environment aspects, and educational institution aspects. TABLE I describes the three aspects of m-learning environment which is required for a HLI to investigate for implementing m-learning environment into the traditional learning environment [5].

TABLE I

ASPECTS OF EMBEDDING M-LEARNING INTO HLI

\begin{tabular}{|l|l|}
\hline \multicolumn{1}{|c|}{ Aspects Type } & \multicolumn{1}{c|}{ Factors to be considered } \\
\hline $\begin{array}{l}\text { Technological } \\
\text { Aspects }\end{array}$ & $\begin{array}{l}\text { Availability, Response times, Flexibility, Scalability, Usability, Maintainability, Functionality, Reliability, } \\
\text { Performance \& Efficiency, Connectivity, User interface, Security. }\end{array}$ \\
\hline $\begin{array}{l}\text { Learning } \\
\text { Environment } \\
\text { aspects }\end{array}$ & $\begin{array}{l}\text { Learner's perspective: the optimization of student autonomy, collaboration, interaction, communication, learning } \\
\text { attitudes, perceiving of knowledge, generating, implementing and sharing of ideas, experimentations, understandable, } \\
\text { usefulness, and accessibility of learning materials, proper guideline for new learning environment, balanced } \\
\text { assessments, etc. } \\
\text { Educator's perspective: effective teaching methodologies irrespective of different abilities, sexes, or ethnic } \\
\text { backgrounds, adaptiveness of introducing a new or changed learning environment, preparation of adequate and } \\
\text { adaptable learning materials according to the learning environment demands, quality of the outcome of the students, } \\
\text { fair assessment of the students' abilities, multiple method of assessment, full control of the classroom, etc. }\end{array}$ \\
\hline $\begin{array}{l}\text { Education } \\
\text { Institution } \\
\text { aspects }\end{array}$ & $\begin{array}{l}\text { Input: The student and research works/projects } \\
\text { Process: Teachers, learning environment, methods, and resources, research practices and methodologies, etc. } \\
\text { Output: Quality graduates and research outcomes. }\end{array}$ \\
\hline
\end{tabular}

\section{A. Educational Supply Chain Management Model}

The educational supply chain model works within and around the entities of a university. External entities like employers of its graduates, secondary and higher secondary schools and colleges and internal entities like its current students and alumni, university staff in designing curricula [12]-[14]. The involvement of entities in the model assures the satisfaction of all stakeholders.

Measuring the performance of an educational institution based on the input, process and output is very challenging. It requires a complete set of performance measurement criteria, factors, stakeholders, etc. along with their properties and characteristics. Integrated Tertiary Education Supply Chain Management (ITESCM) empirical model offers the potential investor as well as the current administrators of the universities of tertiary level a novel methodology for achieving their ultimate target of the creation of highly skilled graduates and novel research outcomes for society's betterment [15]. The model incorporates all the stakeholders of the tertiary educational institution, (four) factors - Program Establishment (PE), Faculty Capabilities (FC), University Culture (UC), and Facilities (FA) of the HLI. TABLE II describes the four factors of the ITESCM model for HLI [16].

\section{TABLE II}

\section{FACTORS IN ITESCM FOR HLI}

\begin{tabular}{|c|c|}
\hline Factors & Involvement in ITESCM model \\
\hline $\begin{array}{l}\text { Programs } \\
\text { Establishment } \\
\quad(\text { PE) }\end{array}$ & $\begin{array}{l}\text { Design and launch different academic programs using a variety of innovative practices to enhance and evaluate the } \\
\text { deviation in education and research in terms of academic practices (teaching-learning methodology, environment, etc.), } \\
\text { practical knowledge \& skills (hands-on, visual, visit, etc.), progression of facilities (ICT, library, etc.), industrial } \\
\text { placements (internship, employment, etc.) etc. }\end{array}$ \\
\hline $\begin{array}{l}\text { Faculty } \\
\text { Capabilities } \\
\text { (FE) }\end{array}$ & $\begin{array}{l}\text { Teaching, research, and academic services to ensure the best classroom environment, enable effective communication, } \\
\text { demonstrate best practices, etc. through instruction, research, learning material preparation, curriculum development, } \\
\text { etc. }\end{array}$ \\
\hline $\begin{array}{l}\text { University } \\
\text { Culture (UC) }\end{array}$ & $\begin{array}{l}\text { The culture of the organization depends on the administrator or management of the university, geographical location and } \\
\text { social practices which also dictates the culture of the universities. }\end{array}$ \\
\hline Facilities (FA) & $\begin{array}{l}\text { The IT infrastructure and their services, digital libraries and their environment, and laboratories and their availability are } \\
\text { some of the modern-day facilities which are essential component for up-to-date learning environment in a tertiary } \\
\text { educational institution. These ensure inclusive academic environments such as, internet-based education, advanced } \\
\text { online learning technology equipped classrooms, well-equipped and facilitated laboratories, research facilities with easy } \\
\text { and frequent access to online resources (e.g., e-book, conference proceedings, e-journal) etc. These facilities enable the } \\
\text { students to learn, both efficiently and conveniently. }\end{array}$ \\
\hline
\end{tabular}


Integrating m-learning into the educational supply chain management, considering an educational institution as a service industry, would require the service industry basics using supply chain management. The factors of service industry - service providers, suppliers, consumers, customers, can be mapped with the factors of educational institution as service industry. The mapping of each of the factors of the education supply chain management with the basics of the service industry must maintain connection all the three decision levels - Strategic level (SL), Planning level (PL), and Operating level (OL) [12][14].

Fig. 1 shows the basics of supply chain as service industry.

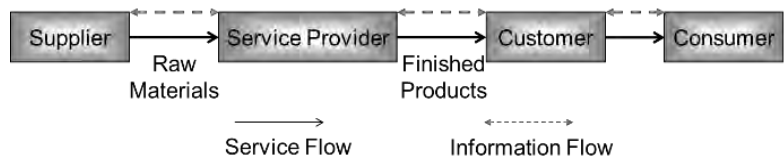

Fig. 1. Service Industry Basics using Supply Chain

ITESCM model is a combined procedure of academic supply chain management for the universities consisting of the educational management, educational supply chain, and research supply chain. TABLE III gives the mapping of service industry factors with the education and research supply chain [15].

TABLE III

EDUCATIONAL INSTITUTION AS SERVICE INDUSTRY USING SUPPLY CHAIN MANAGEMENT

\begin{tabular}{|c|c|c|c|}
\hline \multirow[t]{2}{*}{ 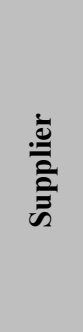 } & Education & \multicolumn{2}{|c|}{$\begin{array}{l}\text { Human Suppliers: } \\
\text { - high schools \& colleges supplying students } \\
\text { - universities supplying faculty members } \\
\text { Non-human Suppliers: } \\
\text { - asset suppliers like, ICT facilities, furniture, etc. } \\
\text { - educational materials like, instruction, stationary, etc. } \\
\text { - fund suppliers like, self-funded, parents, organizational scholarships, grant, allowances, etc. }\end{array}$} \\
\hline & Research & \multicolumn{2}{|c|}{$\begin{array}{l}\text { Internal suppliers: university self -funded research projects } \\
\text { External Suppliers: organizations (private/public), government, etc. }\end{array}$} \\
\hline 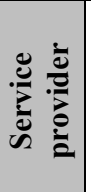 & $\begin{array}{l}\text { Education \& } \\
\text { Research }\end{array}$ & $\begin{array}{l}\text { Two major aspects for both education \& research } \\
\text { - Assessment } \\
\text { - Development }\end{array}$ & $\begin{array}{l}\text { Four main events for all major aspects - } \\
\text { - Programs Establishment (PE) } \\
\text { - University Culture (UC) } \\
\text { - Faculty Capabilities (FC) } \\
\text { - Facilities (FA) }\end{array}$ \\
\hline \multirow{2}{*}{$\stackrel{\stackrel{\Xi}{ٍ:}}{\stackrel{\Xi}{0}}$} & $\begin{array}{l}\text { Quality } \\
\text { Graduates }\end{array}$ & \multicolumn{2}{|c|}{$\begin{array}{l}\text { The university recognizes, identifies, and unifies the standards and the determinants of value addition in the } \\
\text { university process to generate quality graduates. These graduates possess implicit and explicit knowledge, } \\
\text { professional enrichment, proficiencies, aptitudes, expertise, morals, etc. }\end{array}$} \\
\hline & $\begin{array}{l}\text { Research } \\
\text { outcome }\end{array}$ & \multicolumn{2}{|c|}{$\begin{array}{l}\text { The research results may be delivered in form of resolution to the existing problem, development and expansion } \\
\text { of pure theory, scholarly publications, investigative projects, theoretical \& applied research, dissertation, or any } \\
\text { other research outcomes. }\end{array}$} \\
\hline \multirow{2}{*}{ 离 } & Education & \multicolumn{2}{|c|}{ graduates, employers of various public and private sectors, government, NGOs, family members, etc. } \\
\hline & Research & \multicolumn{2}{|c|}{$\begin{array}{l}\text { The research output is consumed by the organizations or donors (like INFORMS, ACM, IEEE, IEOM, etc.) who } \\
\text { provides funding/scope/facilities to the research projects such as, scientific publications, scholars, results, thesis, } \\
\text { PhD dissertation, etc. }\end{array}$} \\
\hline \multicolumn{2}{|c|}{ Consumer } & \multicolumn{2}{|c|}{ The society consuming the final outcomes - graduates \& research. } \\
\hline
\end{tabular}

These supply chains are independent chains with their own characteristics considering the appropriate teaching and research activities which are the two most basic functionality of any tertiary academic institutions [17].

The developed countries prioritize higher education as it plays a major role in the economic development of a society. It provides advanced skills that command a premium in today's workplace. This enables high productivity and improved quality of life [18]-[20]. The ITESCM model considers this and put society as the consumer of the outcome of the institution.

Educational supply chain management produces several competitive advantages with its customer driven vision. These advantages are achieved by improving productivity of learning, boosting educators' \& learners' satisfaction, producing quality graduates and research. Progressively, many final outcomes are recognizing the partnership with the employers in maintaining quality in their education supply chains with potential benefits [21].

The efficiency of the ITESCM model concept can be tested and observed in established academic organizations with different settings. The learning environment setting of ITESCM can be incorporated with additional learning environment, such as m-learning, which enhances the scope of this research to another strong aspect [5].

Fig. 2 illustrates the revised form of original ITESCM model that is easily understandable and more user friendly for practical field applications for educational institutions. 


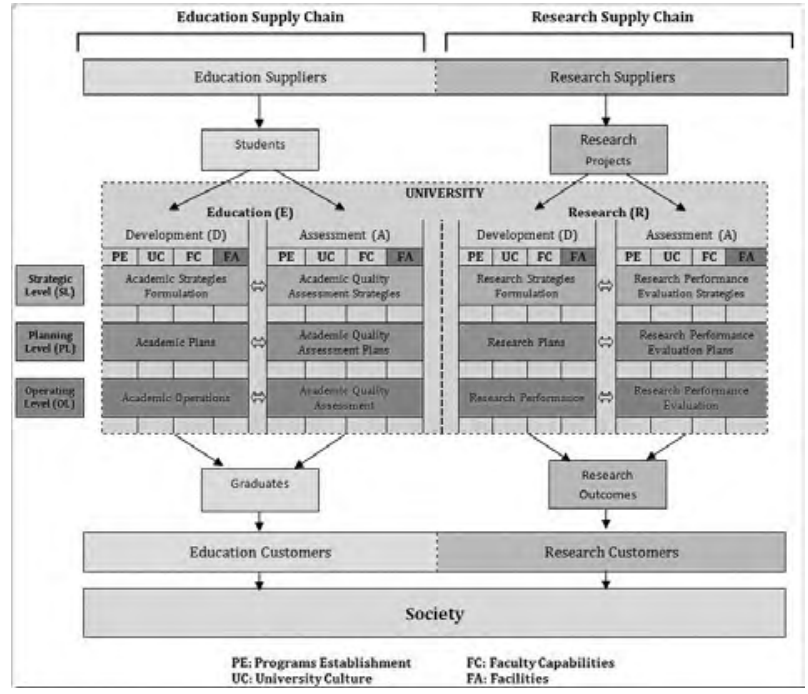

Fig. 2. Redesigned ITESCM Model [21]

\section{EMBEDDING M-LEARNING ASPECTS WITH ITESCM}

M-Learning integrated ITESCM model would give us a better understanding of an integrated learning environment. This would also help to formulate the requirements, roadmap, or guideline to anticipate the impact on the educational outcome using this model. This study evaluates and reduces the risks by increasing the understanding this integrated learning environment under the integrated ESCM model parameters so that the drawbacks can be overcome. This would also be helpful in incorporating and measuring the possibilities of many additional learners who endure their thrust for gaining knowledge even if they are unable to attain the knowledge with the traditional learning environment settings.

The inclusion of m-learning into the educational supply chain management model creates multiple hierarchical decision-making phases as the stakeholders of the ESCM belongs to different hierarchical positions in terms of decisionmaking within the SCM. The mapping of the unique attributes of the m-learning features with formal learning attributes (e.g., cohorts, campuses, courses, semesters, and assessments) along with its monitoring and evaluation regimes puts $\mathrm{m}$-learning in a different characterization. Any changes in these features raises concerns in terms of sustainable deployment in largescale, as the nature and the extent of such deployment may compromise or misplace the unique attributes of both formal learning and m-learning [22].

Integrated Tertiary Educational Supply Chain (ITESCM) model has been used to map the education outcome with different criteria \& aspects of m-learning and established a set of integration criteria to embed m-learning into ESCM model [16].

All the three aspects can be embedded into the factors Program Establishment (PE), University Culture (UC), Faculty Capabilities (FC), and Facilities (FA) in three decision levels Strategic (SL), Planning (PL), and Operating (OL) with the Development \& Assessment for both Education and Research supply chain of ITESCM model [16]. Fig. 3 shows the embedded procedure of m-learning aspects and the components of ITESCM model.

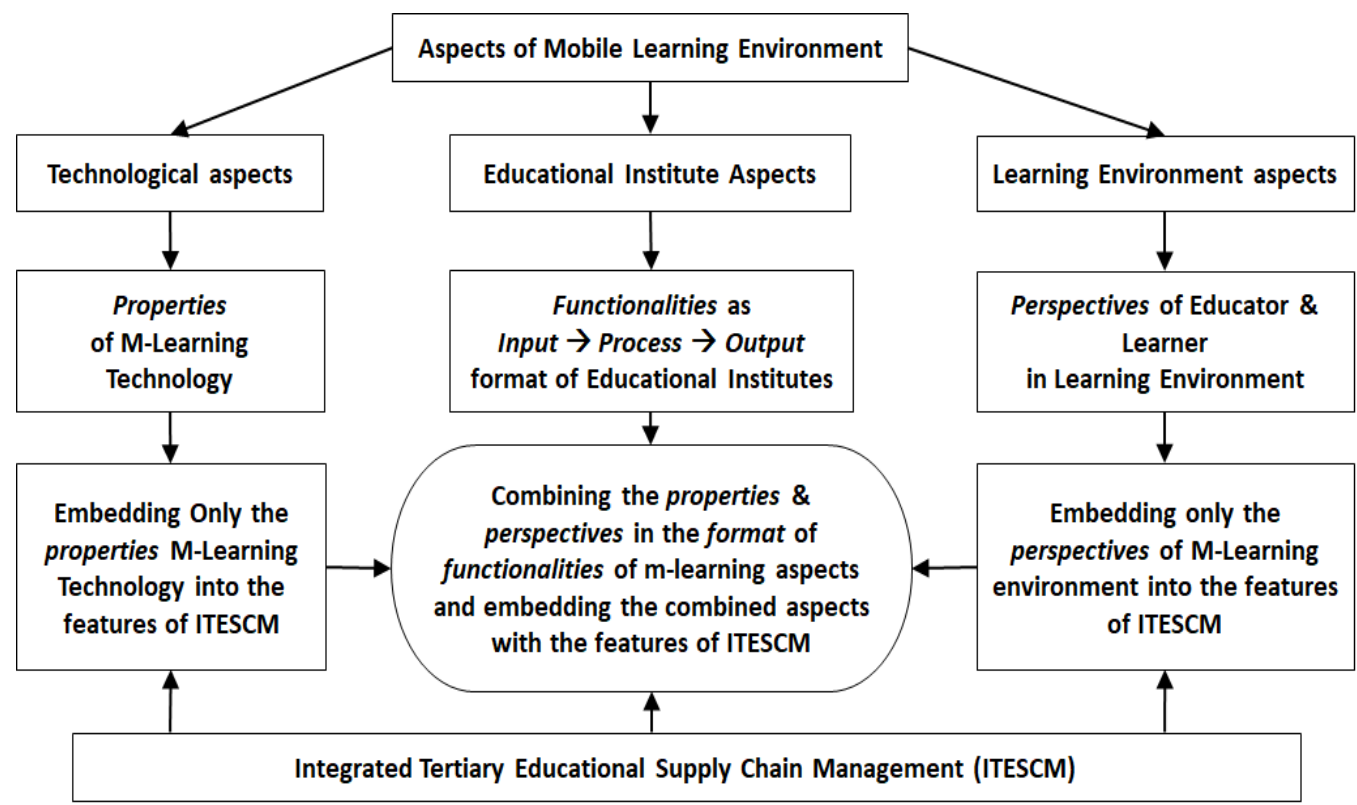

Fig. 3. Embedding Procedure

The following TABLE IV contain the embedded mlearning aspects into ITESCM model respectively for education and research. Each cell of the table contains the features, attributes, processes, measurement, functions, etc. that is required to deal with for the development and assessment for both education and research under the four factors of the university in three decision levels in ITESCM model with respect to the three m-learning aspects. TABLE IV is the combination of both technological and learning environment aspects of m-learning in terms of input, process, and output of educational institution aspects [5] showed in Fig. 3. 
TABLE IV

M-LEARNING ASPECTS EMBEDDED INTO ITESCM (EDUCATION \& RESEARCH) [5], [22], [31]-[40], [23], [41]-[50], [24], [51]-[60], [25], [61], [26]-[30]

\begin{tabular}{|c|c|c|c|c|c|c|c|}
\hline \multicolumn{8}{|c|}{ EMBEDDED ITESCM WITH M-LEARNING ASPECTS } \\
\hline \multicolumn{2}{|c|}{$\begin{array}{l}\text { SUPPLY } \\
\text { CHAINS }\end{array}$} & \multicolumn{3}{|c|}{ EDUCATION SUPPLY CHAIN: } & \multicolumn{3}{|c|}{ RESEARCH SUPPLY CHAIN: } \\
\hline \multicolumn{2}{|c|}{ INPUT } & \multicolumn{3}{|c|}{$\begin{array}{l}\text { EDUCATION SUPPLIERS: } \\
\text { ICT equipment (hardware/software), ICT trained faculty members, } \\
\text { M-Learning based learning materials, teaching methodologies, etc. }\end{array}$} & \multicolumn{3}{|c|}{$\begin{array}{c}\text { RESEARCH SUPPLIERS: } \\
\begin{array}{c}\text { research portal, mobile device access to server, connectivity } \\
\text { with other researchers through mobile devices, etc. }\end{array} \\
\end{array}$} \\
\hline \multicolumn{2}{|c|}{ PROCESS } & DEVELOPMENT & \multicolumn{2}{|c|}{ ASSESSMENT } & DEVELOPMENT & \multicolumn{2}{|c|}{ ASSESSMENT } \\
\hline \multirow{3}{*}{$\mathbf{P E}$} & SL & $\begin{array}{l}\text { Curriculum outcome for all } \\
\text { courses in integrated learning } \\
\text { environment. }\end{array}$ & \multicolumn{2}{|c|}{$\begin{array}{l}\text { Integrated assessment policies to } \\
\text { achieve the outcome of the } \\
\text { curriculum using ICT system. }\end{array}$} & $\begin{array}{l}\text { Adaptability of conducting } \\
\text { research using } \text { m-learning } \\
\text { environment. }\end{array}$ & \multicolumn{2}{|c|}{$\begin{array}{l}\text { Policies to ensure authenticity } \\
\text { and security for m-learning } \\
\text { system. }\end{array}$} \\
\hline & PL & $\begin{array}{l}\text { Define \& design m-learning } \\
\text { component of each course. }\end{array}$ & \multicolumn{2}{|c|}{$\begin{array}{l}\text { Assessment criteria for each } \\
\text { component within the course. }\end{array}$} & $\begin{array}{l}\text { Parameters for all research } \\
\text { components on the m- } \\
\text { learning platform. }\end{array}$ & \multicolumn{2}{|c|}{$\begin{array}{l}\text { Acceptability in research } \\
\text { community using the m- } \\
\text { learning platform. }\end{array}$} \\
\hline & OL & $\begin{array}{l}\text { Partial/full implementation for } \\
\text { selective or all courses using } \\
\text { the m-learning platform. }\end{array}$ & \multicolumn{2}{|c|}{$\begin{array}{l}\text { Assessment criteria, Security \& } \\
\text { validity of the system fulfils the } \\
\text { expectation of the student } \\
\text { outcome. }\end{array}$} & $\begin{array}{l}\text { Learning \& using of the } \\
\text { platform under standard } \\
\text { research guidelines. }\end{array}$ & \multicolumn{2}{|c|}{$\begin{array}{l}\text { Accepted research outcome } \\
\text { with standard, usability, } \\
\text { security, validity, and time } \\
\text { constraints. }\end{array}$} \\
\hline \multirow{3}{*}{$\mathbf{U C}$} & SL & $\begin{array}{l}\text { Robust use of the m-learning } \\
\text { through ICT applications for } \\
\text { academic \& non-academic } \\
\text { functions. }\end{array}$ & \multicolumn{2}{|c|}{$\begin{array}{l}\text { Level of adaptability and } \\
\text { satisfaction of the use of m- } \\
\text { learning and its application for all } \\
\text { stakeholders. }\end{array}$} & $\begin{array}{l}\text { Multiple use criteria with } \\
\text { required resources through } \\
\text { the m-learning concept for all } \\
\text { research activities. }\end{array}$ & \multicolumn{2}{|c|}{$\begin{array}{l}\text { Level of adaptability, } \\
\text { acceptability, connectivity of } \\
\text { the research process using the } \\
\text { applications. }\end{array}$} \\
\hline & $\mathbf{P L}$ & $\begin{array}{l}\text { Regular update \& inclusion of } \\
\text { new academic \& non-academic } \\
\text { areas into m-learning } \\
\text { environment with latest } \\
\text { technologies. }\end{array}$ & \multicolumn{2}{|c|}{$\begin{array}{l}\text { The inclusion must be adequate, } \\
\text { rational, appropriate with user } \\
\text { satisfaction towards the updated } \\
\text { version of the applications. }\end{array}$} & $\begin{array}{l}\text { Regular inclusion of new and } \\
\text { latest methodologies using } \\
\text { latest update of m-learning } \\
\text { applications. }\end{array}$ & \multicolumn{2}{|c|}{$\begin{array}{l}\text { Maintain the defined } \\
\text { parameter of research process } \\
\text { and outcome with latest } \\
\text { features in the m-learning } \\
\text { system. }\end{array}$} \\
\hline & OL & $\begin{array}{l}\text { Proper awareness } \\
\text { implementation for } \\
\text { stakeholders }\end{array}$ & \multicolumn{2}{|c|}{$\begin{array}{l}\text { Time \& effort to adapt the latest } \\
\text { inclusion. }\end{array}$} & $\begin{array}{l}\text { Acceptable, responsive, } \\
\text { usable, \& available to all the } \\
\text { stakeholders }\end{array}$ & \multicolumn{2}{|c|}{$\begin{array}{l}\text { Time \& effort to adapt the } \\
\text { latest research process and } \\
\text { system updates. }\end{array}$} \\
\hline \multirow{3}{*}{ FC } & SL & $\begin{array}{l}\text { Irrespective of ICT } \\
\text { background, teachers must be } \\
\text { set to collect, use, prepare, and } \\
\text { deliver learning materials. }\end{array}$ & \multicolumn{2}{|c|}{$\begin{array}{l}\text { Compliance of a fair assessment } \\
\text { policies, criteria, and process to } \\
\text { evaluate the students with } \\
\text { integrated } \\
\text { components. }\end{array}$} & $\begin{array}{l}\text { Irrespective of ICT } \\
\text { background, researchers must } \\
\text { be set to collect, use, prepare, } \\
\text { and deliver research } \\
\text { materials. }\end{array}$ & \multicolumn{2}{|c|}{$\begin{array}{l}\text { Assessment policies, criteria, } \\
\text { and process to evaluate the } \\
\text { research outcome through m- } \\
\text { learning process. }\end{array}$} \\
\hline & $\mathbf{P L}$ & $\begin{array}{lr}\text { Training, } & \text { teaching } \\
\text { methodologies, } & \text { learning } \\
\text { materials, } & \text { flexibility, } \\
\text { connectivity, etc. } & \\
\end{array}$ & \multicolumn{2}{|c|}{$\begin{array}{l}\text { Students' outcome of knowledge } \\
\text { gathering and implementing using } \\
\text { the system. }\end{array}$} & $\begin{array}{l}\text { Training, relevant research } \\
\text { methodologies, adaptability, } \\
\text { acceptability, connectivity, } \\
\text { etc. }\end{array}$ & \multicolumn{2}{|c|}{$\begin{array}{l}\text { Use of m-learning process for } \\
\text { research outcome in } \\
\text { knowledge implementing, } \\
\text { building, \& sharing. }\end{array}$} \\
\hline & $\overline{\mathbf{O L}}$ & $\begin{array}{l}\text { Preparing \& delivering } \\
\text { learning materials based on } \mathrm{m}- \\
\text { learning applications. }\end{array}$ & \multicolumn{2}{|c|}{$\begin{array}{l}\text { Adequate assessment process to } \\
\text { evaluate the comprehensibility of } \\
\text { the materials delivered. }\end{array}$} & $\begin{array}{l}\text { pare, practice, deliver, } \& \\
\text { lement research materials } \\
\text { ed on m-learning process. }\end{array}$ & \multicolumn{2}{|c|}{$\begin{array}{l}\text { Acceptable assessment process } \\
\text { to evaluate the worth of the } \\
\text { research materials delivered. }\end{array}$} \\
\hline \multirow{3}{*}{ FA } & SL & $\begin{array}{l}\text { ICT infrastructure within and } \\
\text { outside classrooms, m-learning } \\
\text { based applications. }\end{array}$ & \multicolumn{2}{|c|}{$\begin{array}{l}\text { Connectivity, reliability, privacy, } \\
\text { services, troubleshoot, etc. }\end{array}$} & $\begin{array}{l}\text { ICT infrastructure \& } \mathrm{m}- \\
\text { learning applications with } \\
\text { compliance to the need of the } \\
\text { research process. }\end{array}$ & \multicolumn{2}{|c|}{$\begin{array}{l}\text { Connectivity, acceptability, } \\
\text { reliability, privacy, etc. }\end{array}$} \\
\hline & PL & $\begin{array}{l}\text { Scope of the ICT infrastructure } \\
\text { to strengthen the knowledge } \\
\text { building. }\end{array}$ & \multicolumn{2}{|c|}{ User satisfaction, students' output. } & $\begin{array}{l}\text { Scope of the ICT } \\
\text { infrastructure to support the } \\
\text { research process. }\end{array}$ & \multicolumn{2}{|c|}{ Stakeholders' satisfaction. } \\
\hline & OL & $\begin{array}{l}\text { Implementation, maintenance, } \\
\& \text { update. }\end{array}$ & Scalabi & etc. & $\begin{array}{l}\text { Implementation, } \\
\text { maintenance, \& update. }\end{array}$ & $\begin{array}{l}\text { Scala } \\
\text { perfo }\end{array}$ & $\begin{array}{l}\text { functionality, } \\
\text { e, etc. }\end{array}$ \\
\hline & & OUTCOME & & CONSUMER & $\begin{array}{ll}\text { FINAL OUTCOME } \\
\end{array}$ & & SUMER \\
\hline $\mathbf{O U}$ & PUT & $\begin{array}{l}\text { GRADUATES: quality graduate } \\
\text { with latest technologies displayi } \\
\text { and explicit knowledge, pro } \\
\text { aptitudes, expertise, morals, p } \\
\text { enrichment, etc. }\end{array}$ & $\begin{array}{l}\text { quipped } \\
\text { implicit } \\
\text { ciencies, } \\
\text { fessional }\end{array}$ & $\begin{array}{l}\text { SOCIETY: Utilizes } \\
\text { the graduates through } \\
\text { the employers and/or } \\
\text { entrepreneurship to } \\
\text { expand the society }\end{array}$ & $\begin{array}{l}\text { RESEARCH OUTCOMES: } r \\
\text { to the existing problem, develo } \\
\text { expansion of pure theory, } \\
\text { publications, investigative } \\
\text { theoretical \& applied research, }\end{array}$ & $\begin{array}{l}\text { solution } \\
\text { ment \& } \\
\text { cholarly } \\
\text { projects, } \\
\text { tc. }\end{array}$ & $\begin{array}{l}\text { SOCIETY: } \\
\text { Implements the } \\
\text { research outcome } \\
\text { through the } \\
\text { public/private }\end{array}$ \\
\hline & & $\begin{array}{l}\text { EDUCATION CUSTOMERS } \\
\text { family members, employers of } \\
\text { and private organizations. }\end{array}$ & $\begin{array}{l}\text { raduates, } \\
\text { rernment }\end{array}$ & & $\begin{array}{l}\text { RESEARCH CUSTOMER } \\
\text { organizations or donors who } \\
\text { funding/scope/facilities to the } \\
\text { projects. }\end{array}$ & $\begin{array}{l}\text { the } \\
\text { rovides } \\
\text { esearch }\end{array}$ & $\begin{array}{l}\text { organizations to } \\
\text { develop the society }\end{array}$ \\
\hline
\end{tabular}

\section{INTEGRATION OF M-LEARNING INTO ITESCM}

The aspects of educational institution and the m-learning environment needs to be embedded to create an integrated model to implement a new process (m-learning) into the traditional process (traditional learning). The model needs to be in a format where the administrators [16] -

- $\quad$ can provide the required elements to implement m-learning as input into the model, 
- identify, measure, and formulate the impact \& relationship among the aspects and the factors for each aspect at different decision levels as process, and

- $\quad$ examine if the required educational outcome is achieved as output.

The educational institution aspects are identified through the input, process, and output of the institution itself.

- The input in terms of m-learning aspects are the suppliers of education and research for technological and learning environment aspects.

- The process are the development and assessment of education and research in terms of four factors - Program Establishment (PE), University Culture (UC), Faculty Capabilities (FC), Facilities (FA) of the university, each under the three decision levels - Strategic (SL), Planning (PL), Operation (OL).
- Finally, the output is the graduates and research outcome into the society. The technological aspects and the learning environment aspects are combined to map the factors of educational institution aspects.

The following Fig. 4 illustrates the integration process to create the Integrated M-learning Education Supply Chain Management (IMLESCM) model. The embedded factors of the m-learning aspects from TABLE IV are integrated in three phases - Input, Process, and Output.

- The embedded input factors map with the Suppliers for both Education \& Research, respectively.

- The embedded process factors map with the Service provider for both Education \& Research respectively.

- The embedded output factors map with the Outcome \& Consumer for both Education \& Research, respectively.

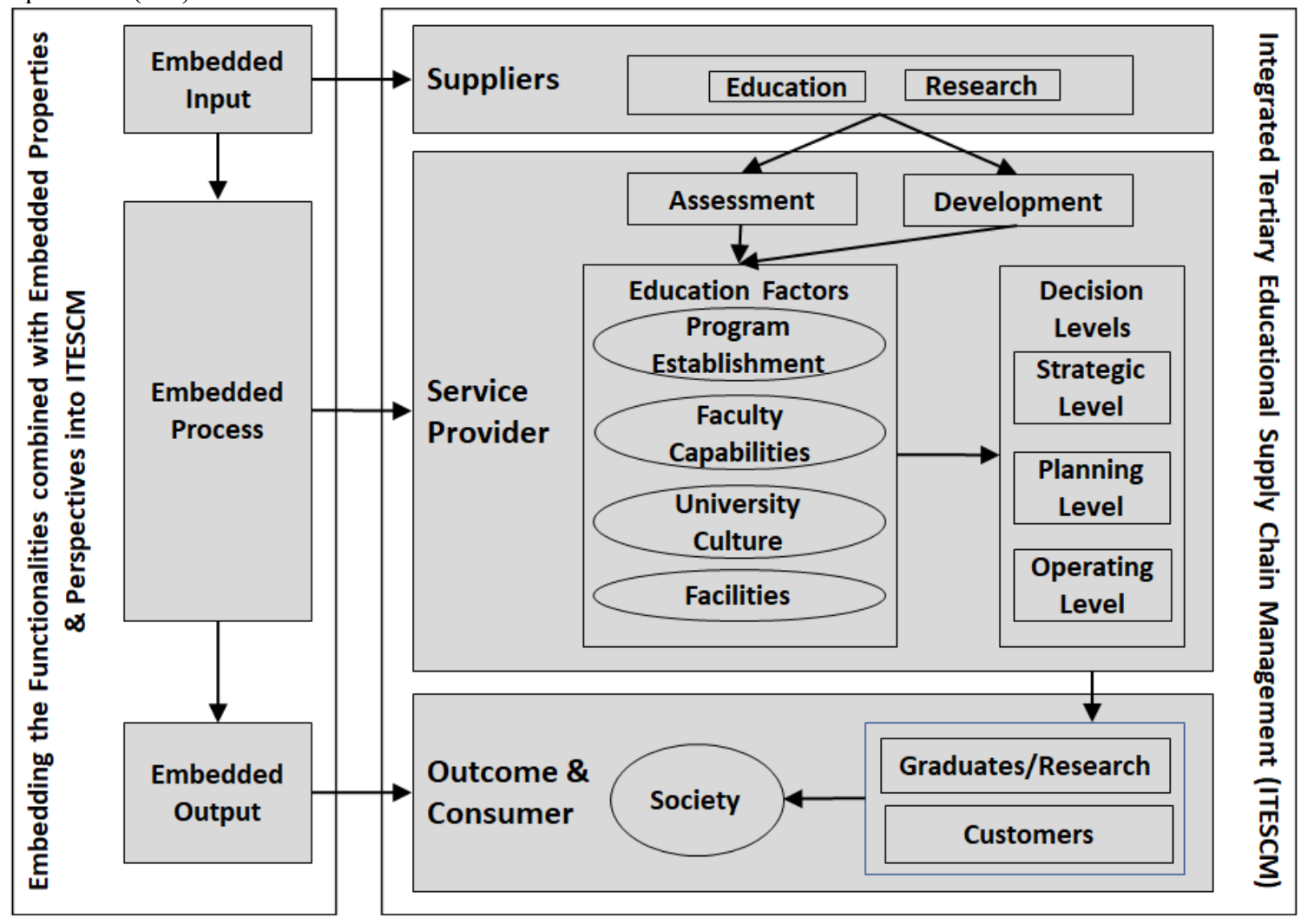

Fig. 4. Integrated Mobile Learning Educational Supply Chain Management (IMLESCM) Model

The IMLESCM model is a combination of education supply chain and research supply chain. In both chains, there are three inputs and three outputs as embedded in the TABLE IV. The following two figures, Fig. 5 and Fig. 6, shows both the supply chains in detail. 


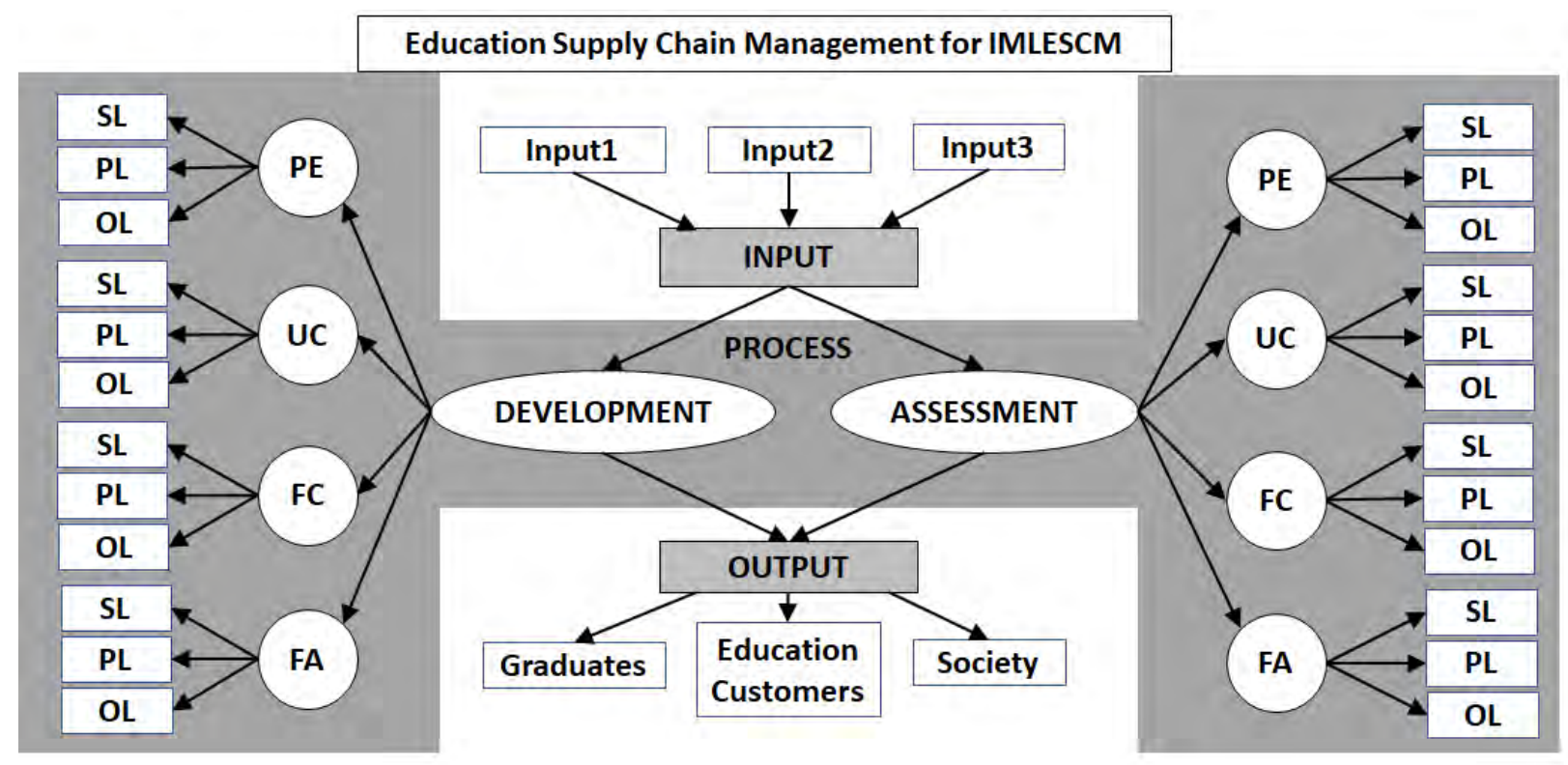

Fig. 5. IMLESCM: Education Supply Chain

Fig. 5 shows the education supply chain of the model IMLESCM. There are three inputs based on the embedded criteria of m-learning environment - infrastructure development (availability, cost, maintenance, etc.), human resource \& learning materials (training, teaching methodology, learning materials, assessment process, etc.), and unified $\mathrm{m}$ learning management platform for ease of use and accessibility
[24], [25], [59]-[68], [26]-[28], [33], [43], [55], [56], [58]. The process contains all the four factors for three decision levels for both development and assessment phases. There are three outputs - quality of graduates as outcome, meets the requirement of education customers (e.g., employers), and the societies advancement as the overall consumer of the outcome.

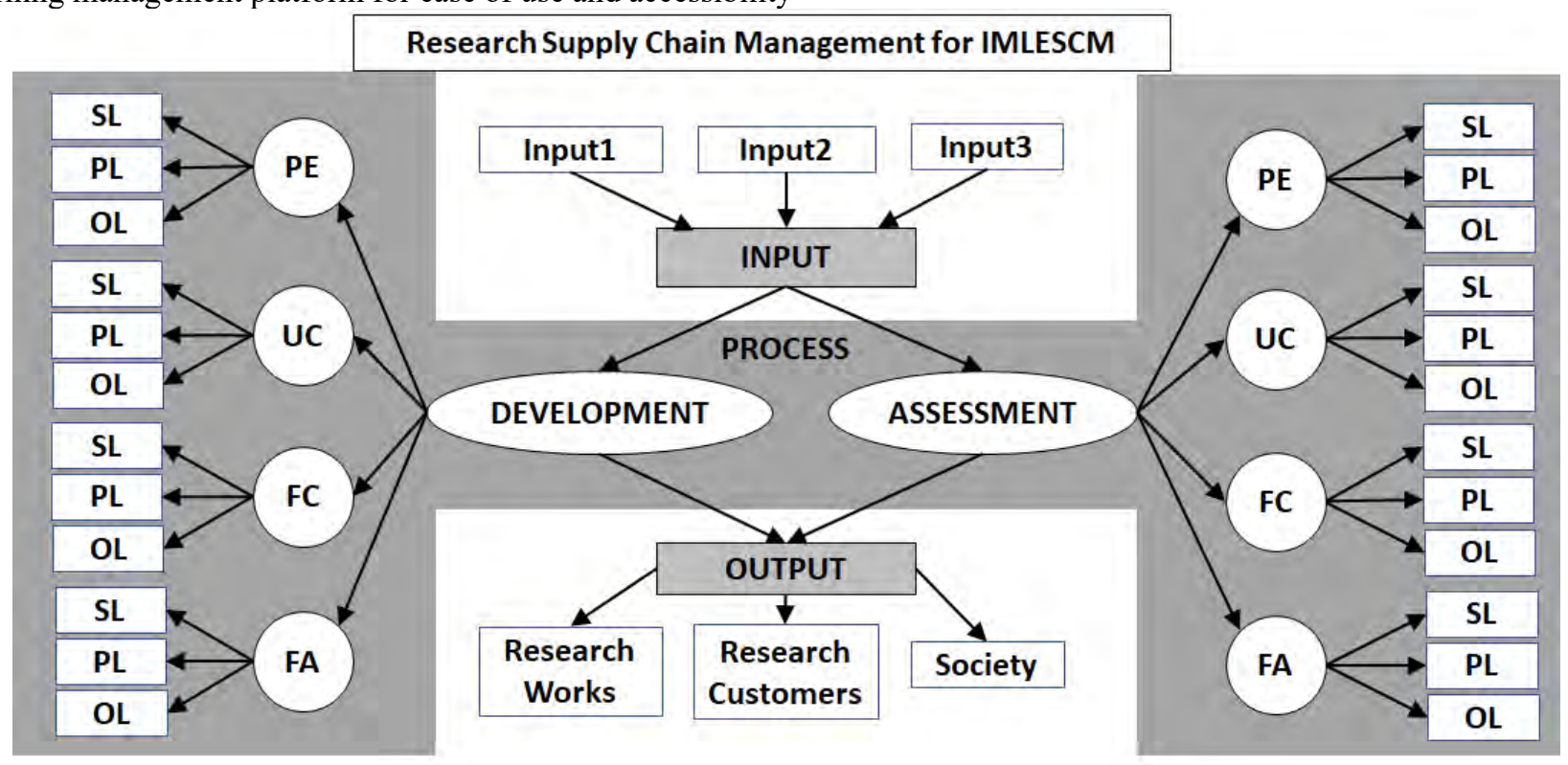

Fig. 6. IMLESCM: Research Supply Chain

Fig. 6 shows the research supply chain of the model IMLESCM. There are three inputs based on the embedded criteria of m-learning environment - infrastructure development (availability, cost, maintenance, etc.), human resource \& research materials (training, research methodology, research materials, research outcome, etc.), and unified mlearning management platform for ease of use and accessibility
[24], [25], [65], [66], [33], [58]-[64]. The process contains all the four factors for three decision levels for both development and assessment phases. There are three outputs - research outcome, meets the requirement of research customers (e.g., research funding agencies), and the societies advancement as the overall consumer of the outcome. 


\section{CONCLUSION}

This study illustrates an integrated mobile learning education supply chain management (IMLESCM) model for the aspects of m-learning environment and the educational institution. The m-learning environment aspects were studied and identified. These aspects were embedded into each of the phases, aspects, factors, and levels of an empirical education supply chain model. The next step for this research is to collect data from different stakeholder of the IMLESCM model with respect to the institutional input, process, and output structure. These collected data from the stakeholders will also require an organized methodology towards a considerate process to test the reliability of the model, identify the integration criteria, assessment criteria, and most importantly to initiate and sustain the new integrated model for all relevant stakeholders of an academic institution.

Finally, these embedded aspects of m-learning were integrated into the ITESCM model in the format - input, process, and output. The goal was to develop a model that can take the supplies for implementing m-learning environment as input into the model by the stakeholder of the universities, process the decision levels of the stakeholder of the universities in different factors of the phases of the model, and ultimately provide an output that gives the quality of products, i.e. graduates and research outcomes for the betterment of the consumer, i.e. the Society.

\section{REFERENCES}

M. Almarwani, "E3-Electronic Education for English: Developing mobile learning and teaching in Saudi Arabia.," in 8th annual International Conference on Education and New Learning Technologies (EDULEARN16), 2016, no. July, [Online]. Available: http://eprints.lincoln.ac.uk/24208/1/24208 AlMarwaniManalEducation-July 2016.pdf.

[2] H. Crompton and D. Burke, "The use of mobile learning in higher education: A systematic review," Comput. Educ., vol. 123, no. April, pp. 53-64, 2018, doi: 10.1016/j.compedu.2018.04.007.

[3] M. Á. Conde, F. J. García-Peñalvo, M. J. Rodríguez-Conde, M. Alier, M. J. Casany, and J. Piguillem, "An evolving Learning Management System for new educational environments using 2.0 tools," Interact. Learn. Environ., vol. 22, no. 2, pp. 188-204, 2014, doi: $10.1080 / 10494820.2012 .745433$.

[4] M. Al-Emran, I. Arpaci, and S. A. Salloum, “An empirical examination of continuous intention to use m-learning: An integrated model," Educ. Inf. Technol., vol. 25, no. 4, pp. 28992918, 2020, doi: 10.1007/s10639-019-10094-2.

[5] M. Rahman, R. A. Rahman, and M. Habib, "INVESTIGATING DIFFERENT CRITERIA TO INCLUDE M-LEARNING INTO THE TRADITIONAL LEARNING ENVIRONMENT IN HLI," International Conference on Business and Management (ICBM), 2019.

[6] D. A. Sitar-Tăut, "Mobile learning acceptance in social distancing during the COVID-19 outbreak: The mediation effect of hedonic motivation," Hum. Behav. Emerg. Technol., vol. 3, no. 3, pp. 366378, 2021, doi: 10.1002/hbe2.261.

[7] J. M. Romero-Rodriguez, I. Aznar-Diaz, F. J. Hinojo-Lucena, and G. Gomez-Garcia, "Mobile Learning in Higher Education: Structural Equation Model for Good Teaching Practices," IEEE
Access, vol. 8, pp. 91761-91769, 2020, doi: 10.1109/ACCESS.2020.2994967.

[8] D. Garbett and A. Ovens, "Being Self-Study Researchers in a Digital World: An Introduction.," in Being Self-Study Researchers in a Digital World, Self-Study of Teaching and Teacher Education Practices, Vol 16., Springer, Cham, 2017.

[9] A. Chavoshi and H. Hamidi, "Social, individual, technological and pedagogical factors influencing mobile learning acceptance in higher education: A case from Iran," Telemat. Informatics, vol. 38, pp. 133-165, 2019, doi: 10.1016/j.tele.2018.09.007.

[10] D. Keegan, "The future of learning: From eLearning to mLearning," Germany:, 2003. Accessed: Jan. 03, 2019. [Online]. Available: http://files.eric.ed.gov/fulltext/ED472435.pdf.

[11] H. R. Abachi and G. Muhammad, "The impact of m-learning technology on students and educators," Comput. Human Behav., vol. 30, pp. 491-496, Jan. 2014, doi: 10.1016/J.CHB.2013.06.018

[12] M. Habib and C. Jungthirapanich, "An empirical study of educational supply chain management for the Universities," Proc. 2010 Int. Conf. Ind. Eng. Oper. Manag., pp. 292-298, 2010.

[13] A. K. W. Lau, "Educational supply chain management: A case study," Horiz., vol. 15, no. 1, pp. 15-27, 2007, doi: 10.1108/10748120710735239.

[14] E. M. O'Brien and K. R. Deans, "Educational supply chain: a tool for strategic planning in tertiary education?," Mark. Intell. Plan., vol. 14, no. 2, pp. 33-40, Apr. 1996, doi: $10.1108 / 02634509610110787$.

[15] A. K. M. Hye and M. H. Zaman, "Comparative Analysis of Supply Chain Management for Universities through ITESCM Model," pp. 1904-1913, 2014.

[16] M. Rahman, R. A. Rahman, and M. Habib, "EMBEDDING MLEARNING ENVIRONMENT INTO EDUCATION SUPPLY CHAIN MANAGEMENT MODEL FOR HLI," International Conference on Business and Management (ICBM), 2019.

[17] M. Habib and B. B. Pathik, "Redesign Itescm," vol. 1, no. 1, pp. $12-$ 26, 2012.

[18] O.-U. Safiya, K. Ardzejewska, and A. Imran, “A Systematic Review of Mobile Learning Adoption in Higher Education : the African Perspective," i-managers J. Mob. Appl. Technol., vol. 4, no. 2, p. 2017,2015

[19] R. Kaliisa, E. Palmer, and J. Miller, "Mobile learning in higher education: A comparative analysis of developed and developing country contexts," Br. J. Educ. Technol., vol. 50, no. 2, pp. 546561, 2019, doi: 10.1111/bjet.12583.

[20] UNESCO, “UNESCO Mobile Learning Week Report,” Paris, 2011. Accessed: Dec. 27, 2018. [Online]. Available: http://www.unesco.org/new/fileadmin/MULTIMEDIA/HQ/ED/ICT/ $\mathrm{pdf} /$ UNESCO MLW report final 19jan.pdf.

[21] B. B. Pathik and M. M. Habib, "Enhancing supply chain management for the universities: ITESCM model perspective," Int. J. Supply Chain Manag., vol. 1, no. 2, pp. 11-25, 2012.

[22] M. S. Mohamed Ally, Ed., "Guidelines for Design \& Implementation of mLearning," in Revolutionizing modern education through meaningful e-learning implementation, McWeadon Education, USA, 2016, pp. 161-176.

[23] T. Elias, "Universal instructional design principles for mobile learning," Int. Rev. Res. Open Distrib. Learn., vol. 12, no. 2, pp. 143-156, Feb. 2011, doi: 10.19173/irrodl.v12i2.965.

[24] P. Yu-mei, Z. Xue-jun, and L. Li, "Learning Can Happen Anytime and Anywhere: The Application of M-learning in Medical Education," in 2010 Second International Workshop on Education Technology and Computer Science, 2010, pp. 508-511, doi: 10.1109/ETCS.2010.114 
Smartphones and Apps in Higher Education," Educ. Sci. Theory Pract., vol. 14, no. 4, pp. 1505-1520, 2014, doi: 10.12738/estp.2014.4.2012.

[26] B. J. Fraser, K. G. Tobin, and C. J. McRobbie, "Classroom Learning Environments: Retrospect, Context and Prospect," in Second International Handbook of Science Education, Springer I., Springer Science+Business Media B.V. 2012, 2012, pp. 1191-1239.

[27] N. F. D. Filho and E. F. Barbosa, "A requirements catalog for mobile learning environments," in 28th Annual ACM Symposium on Applied Computing - SAC '13, 2013, pp. 1266-1271, doi: $10.1145 / 2480362.2480599$

[28] G.-J. Hwang and H.-F. Chang, “A formative assessment-based mobile learning approach to improving the learning attitudes and achievements of students," Comput. Educ., vol. 56, no. 4, pp. 10231031, May 2011, doi: 10.1016/J.COMPEDU.2010.12.002.

[29] D. Laurillard, Teaching as a Design Science. Routledge, 2013.

[30] B. Fraser, "Classroom Learning Environments," in Encyclopedia of Science Education, R. Gunstone, Ed. Dordrecht: Springer Science+Business Media Dordrecht 2015, 2015, pp. 154-157.

[31] F. Ferreira et al., "Protege: A Mobile Health Application for the Elder-caregiver Monitoring Paradigm," Procedia Technol., vol. 9, pp. 1361-1371, 2013, doi: 10.1016/j.protcy.2013.12.153.

[32] F. Khaddage and J. H. Cosío, "Trends and Barriers on the Fusion of Mobile Apps in Higher Education Where to Next and How?," in (SITE-2014) Society for Information Technology \& Teacher Education International Conference, Mar. 2014, vol. 2014, no. 1, pp. 903-909, doi: 10.13140/RG.2.1.3867.8168.

[33] F. Khaddage, R. Christensen, W. Lai, G. Knezek, C. Norris, and E. Soloway, "A model driven framework to address challenges in a mobile learning environment," Educ. Inf. Technol., vol. 20, no. 4, pp. 625-640, 2015, doi: 10.1007/s10639-015-9400-х.

[34] F. Ozdamli and N. Cavus, "Basic elements and characteristics of mobile learning," Procedia-Social Behav. Sci., vol. 28, pp. 937-942, 2011, doi: 10.1016/j.sbspro.2011.11.173.

[35] P. Zervas, S. E. G. Ardila, R. Fabregat, and D. G. Sampson, "Tools for context-aware learning design and mobile delivery," in Proceedings of the 2011 11th IEEE International Conference on Advanced Learning Technologies, ICALT 2011, 2011, pp. 534-535, doi: 10.1109/ICALT.2011.164.

[36] M. Kearney, S. Schuck, K. Burden, and P. Aubusson, "Viewing mobile learning from a pedagogical perspective," Res. Learn. Technol., vol. 20, no. 1, pp. 1-17, 2012, doi: 10.3402/rlt.v20i0/14406.

[37] H. Norman, "Mobile Learning in Higher Education in the AsiaPacific Region,” vol. 40, no. July, 2017, doi: 10.1007/978-981-104944-6.

[38] T.-T. Goh, B.-C. Seet, and N.-S. Chen, "The impact of persuasive SMS on students' self-regulated learning," Br. J. Educ. Technol., vol. 43, no. 4, pp. 624-640, Jul. 2012, doi: 10.1111/j.14678535.2011.01236.x.

[39] Å. Grönlund and Y. M. Islam, “A mobile e-learning environment for developing countries: The Bangladesh Virtual Interactive Classroom," Inf. Technol. Dev., vol. 16, no. 4, pp. 244-259, 2010, doi: 10.1080/02681101003746490.

[40] A. Hayati, A. Jalilifar, and A. Mashhadi, "Using Short Message Service (SMS) to teach English idioms to EFL students," $B r . J$. Educ. Technol., vol. 44, no. 1, pp. 66-81, 2013, doi: 10.1111/j.14678535.2011.01260.x

[41] Y. Liu, H. Li, and C. Carlsson, "Factors driving the adoption of mlearning: An empirical study," Comput. Educ., vol. 55, no. 3, pp. 1211-1219, Nov. 2010, doi: 10.1016/j.compedu.2010.05.018.

[42] J. C. Sánchez-Prieto, S. Olmos-Migueláñez, and F. J. GarcíaPeñalvo, "Informal tools in formal contexts: Development of a model to assess the acceptance of mobile technologies among teachers," Comput. Human Behav., vol. 55, pp. 519-528, 2016, doi 10.1016/j.chb.2015.07.002.

[43] R. Reis, P. Escudeiro, and N. Escudeiro, "Educational resources for mobile wireless devices: A case study," Proc. 2012 17th IEEE Int. Conf. Wireless, Mob. Ubiquitous Technol. Educ. WMUTE 2012, pp 264-267, 2012, doi: 10.1109/WMUTE.2012.64

[44] T. H. Laine, C. A. I. Sedano, M. Joy, and E. Sutinen, "Critical factors for technology integration in game-based pervasive learning spaces," IEEE Trans. Learn. Technol., vol. 3, no. 4, pp. 294-306, 2010, doi: 10.1109/TLT.2010.16.

[45] L. A. Mills, G. Knezek, and F. Khaddage, "Information Seeking, Information Sharing, and going mobile: Three bridges to informal learning," Comput. Human Behav., vol. 32, pp. 324-334, 2014, doi: 10.1016/j.chb.2013.08.008

[46] M. Sarrab, M. Elbasir, and S. Alnaeli, "Towards a quality model of technical aspects for mobile learning services: An empirical investigation," Comput. Human Behav., vol. 55, pp. 100-112, 2016 , doi: 10.1016/j.chb.2015.09.003.

[47] I. Milošević, D. Živković, D. Manasijević, and D. Nikolić, "The effects of the intended behavior of students in the use of Mlearning," Comput. Human Behav., vol. 51, no. PA, pp. 207-215, 2015, doi: 10.1016/j.chb.2015.04.041.

[48] L. Johnson, B. S. Adams, V. Estrada, and A. Freeman, 2016 NMC Higher Education Horizon Report. 2014.

[49] A. Tugrul Korucu and A. Alkan, "Differences between m-learning (mobile learning) and e-learning, basic terminology and usage of $\mathrm{m}$ learning in education," Procedia - Soc. Behav. Sci., vol. 15, pp. 1925-1930, 2011, doi: 10.1016/j.sbspro.2011.04.029.

[50] S. M. Land and H. T. Zimmerman, "Socio-technical dimensions of an outdoor mobile learning environment: a three-phase design-based research investigation," Educ. Technol. Res. Dev., vol. 63, no. 2, pp. 229-255, 2015, doi: 10.1007/s11423-015-9369-6.

[51] N. Gedik, A. Hanci-Karademirci, E. Kursun, and K. Cagiltay, "Key instructional design issues in a cellular phone-based mobile learning project," Comput. Educ., vol. 58, no. 4, pp. 1149-1159, 2012, doi: 10.1016/j.compedu.2011.12.002.

[52] N. M. Sabah, "Exploring students' awareness and perceptions: Influencing factors and individual differences driving m-learning adoption," Comput. Human Behav., vol. 65, pp. 522-533, 2016, doi: 10.1016/j.chb.2016.09.009

[53] A. Shih-hsien Yang, "EXPLORING COLLEGE STUDENTS ATTITUDES AND SELF-EFFICACY OF MOBILE LEARNING," 2012. Accessed: Dec. 26, 2018. [Online]. Available: https://files.eric.ed.gov/fulltext/EJ989264.pdf.

[54] J. Alden, “ACCOMMODATING MOBILE LEARNING IN COLLEGE PROGRAMS,” J. Asynchronous Learn. Networks, vol. 17, no. 1, pp. 109-122, 2013, Accessed: Dec. 26, 2018. [Online]. Available: https://files.eric.ed.gov/fulltext/EJ1011363.pdf.

[55] N. Vaughan and K. Lawrence, “- Investigating the Role of Mobile Devices in a Blended Pre-Service Teacher Education Program," Can. J. High. Educ., vol. 43, no. 3, pp. 56-78, 2013, doi: 10.4018/978-1-4666-6343-5.ch006.

[56] M. Aresta, L. Pedro, and C. Santos, "MOBILE LEARNING AND HIGHER EDUCATION: A THEORETICAL OVERVIEW," $J$. Mob. Multimed., vol. 1, no. 2, pp. 147-156, 2015, Accessed: Dec. 24, 2018. [Online]. Available:

https://www.riverpublishers.com/journal/journal_articles/RP_Journa 1_1550-4646_11112.pdf.

K.-W. Lai, F. Khaddage, and G. Knezek, "Blending student technology experiences in formal and informal learning," $J$. Comput. Assist. Learn., vol. 29, no. 5, pp. 414-425, Oct. 2013, doi: 10.1111/jcal.12030.

[58] J. Cheon, S. Lee, S. M. Crooks, and J. Song, "An investigation of mobile learning readiness in higher education based on the theory of 
planned behavior," Comput. Educ., vol. 59, no. 3, pp. 1054-1064, 2012, doi: 10.1016/j.compedu.2012.04.015.

[59] E. A. Beckmann, "Learners on the move: Mobile modalities in development studies," Distance Educ., vol. 31, no. 2, pp. 159-173, 2010, doi: 10.1080/01587919.2010.498081.

[60] H.-R. Chen and H.-L. Huang, "User Acceptance of Mobile Knowledge Management Learning System: Design and Analysis.," Educ. Technol. Soc., vol. 13, no. 3, pp. 70-77, 2010, doi: 10.2307/jeductechsoci.13.3.70.

[61] A. Z. Saccol, J. L. V. Barbosa, E. Schlemmer, and N. Reinhard, "Mobile Learning in Organizations," Int. J. Inf. Commun. Technol. Educ., vol. 7, no. 3, pp. 11-24, 2011, doi: 10.4018/jicte.2011070102.

[62] A. Kukulska-Hulme, "Mobile usability in educational contexts: What have we learnt?," Int. Rev. Res. Open Distance Learn., vol. 8, no. 2, 2007, doi: 10.19173/irrodl.v8i2.356.

[63] B. Patten, I. A. Sánchez, and B. Tangney, "Designing collaborative, constructionist and contextual applications for handheld devices," Comput. Educ., vol. 46, no. 3, pp. 294-308, 2006, doi: 10.1016/j.compedu.2005.11.011.

[64] A. A. Economides, "Requirements of mobile learning applications," 2008. Accessed: Dec. 25, 2018. [Online]. Available: http://www.conta.uom.gr/conta/publications/PDF/requirements of mobile learning applications2.pdf.

[65] P. Pocatilu and C. Boja, "Quality Characteristics and Metrics Related To M-Learning Process," Amfiteatru Econ., vol. 11, no. 26, pp. 346-354, 2009, doi: 10.1016/j.saa.2015.06.088.

[66] H. Jenkins, K. Clinton, R. Purushotma, A. J. Robison, and M. Weigel, Confronting the Challenges of Participatory Culture: Media Education for the 21 st Century. MacArthur Foundation, 2006.

[67] C. Crook, "The 'digital native' in context: tensions associated with importing Web 2.0 practices into the school setting," Oxford Rev. Educ., vol. 38, no. 1, pp. 63-80, Feb. 2012, doi: 10.1080/03054985.2011.577946.

[68] T. D. Cochrane, "Exploring mobile learning success factors," ALTJResearch Learn. Technol., vol. 18, no. 2, pp. 133-148, Jul. 2010, doi: 10.1080/09687769.2010.494718.

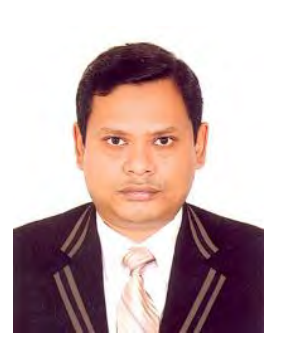

Mashiour Rahman is working as an Associate Professor in the department of Computer Science and Associate Dean of Faculty of Science and Technology in American International UniversityBangladesh (AIUB). He is currently pursuing his $\mathrm{PhD}$ in Decision Science at Universiti Utara Malaysia (UUM). He is a professional member of Association of Computing Machinery (ACM.). His research interest includes Algorithms,
Data structure, M-learning, quantitative analysis, education management etc. He can be contacted at mashiour@gmail.com.

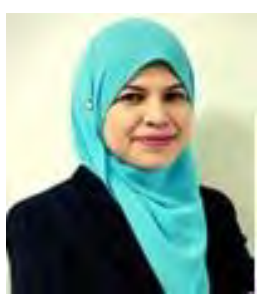

Rosshairy Abd Rahman is a senior lecturer at Decision Science Department, School of Quantitative Sciences, Universiti Utara Malaysia (UUM), Malaysia. She obtained her B.Sc. degree in Statistics from Universiti Kebangsaan Malaysia and M.Sc. Degree in Decision Science from Universiti Utara Malaysia. Her PhD degree is in Decision Science/Operations Research, specifically in Metaheuristics. She is actively supervising $\mathrm{PhD}$ and Masters students in the area of operations research. She teaches Heuristic and Research Methodology subject for undergraduate and postgraduate students. Her intense research areas are in optimization, metaheuristics, evolutionary algorithm, multi-criteria decision analysis, planning and scheduling problems, supply chain and agriculture. Currently, she is a member of the Management Science and Operations Research Society of Malaysia (MSORSM) and a fellow of Institute of Strategic Industrial Decision Modelling (ISIDM), School of Quantitative Sciences, UUM. She can be contacted at shairy@uum.edu.my.

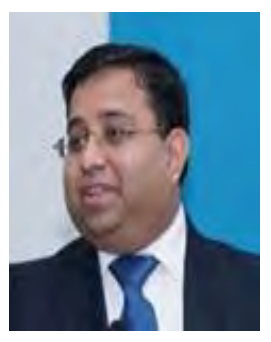

Dr. Md. Mamun Habib is currently working as a Professor at School of Business \& Entrepreneurship (SBE), Independent University, Bangladesh (IUB). Dr. Habib is the Visiting Scientist at the Dept. of Industrial Engineering of University of Texas - Arlington, USA. He is also the Adjunct Professor at Unirazak, Malaysia and UCSI, Malaysia. $\mathrm{He}$ is the Editor-in-Chief in International Journal of Supply Chain Management (IJSCM), London, UK. He serves as the Editor-inChief/Lead Guest Editor/Editor/Editorial Board Member/Reviewer of more than 50 journals. His core research areas are supply chain management, quantitative models, production \& operations management, engineering \& technology management, and educational management. Prof. Habib is an active member of different professional organizations including IEEE (Senior Member), IEOM (President, SCM Technical Division), IETI (Senior Member and Board of Director), IRED (Fellow), GRDS (Vice-President), just to name a few. Finally, He is involved with QS World University Ranking/Times Higher Education Ranking as an academician. He can be contacted at mamunhabib@iub.edu.bd. 